\title{
Reaction of Eyespot Causal Agents to some Active Ingredients of Fungicides In Vitro
}

\author{
J. PALICOvÁ ${ }^{1 *}$ and P. MATUŠINSKY ${ }^{2,3}$ \\ ${ }^{1}$ Crop Research Institute, Drnovská 507, 16106 Prague 6, Czech Republic \\ ${ }^{2}$ Agrotest Fyto, Ltd., Havlíčkova 2787/121, 76701 Kroměříž, Czech Republic \\ ${ }^{3}$ Palacky University, Faculty of Science, Department of Botany, Slechtitelu 27, 78371 Olomouc, \\ Czech Republic
}

(Received 12 July 2018; Accepted 8 August 2018;

Communicated by Á. Mesterházy)

\begin{abstract}
Winter wheat samples infected by eyespot were collected during the years 2015-2017. In total 143 Oculimacula spp. isolates were obtained and determined by PCR. Oculimacula yallundae isolates prevailed (122) over Oculimacula acuformis isolates (12) and 9 mixed isolates of both species. O. acuformis predominated only on one locality. The reaction of 104 Oculimacula spp. isolates to ten different fungicides was evaluated in laboratory tests on Petri dishes. The highest efficacy showed the combination of epoxiconazole + fluxapyroxad + pyraclostrobin and the lowest efficacy was evaluated after application of prothioconazole + trifloxystrobin. The decrease of efficacy of fungicide no. 6 (prothioconazole + trifloxystrobin) has been observed since 2015. The sensitivity of 114 Oculimacula spp. isolates to prochloraz has been tested. More than half of the isolates (58\%) showed low to medium resistance. One isolate of $O$. yallundae from the year 2017 showed high resistance to prochloraz $\left(\mathrm{ED}_{50}\right.$ ranged $\left.1.7 \mu \mathrm{g} \cdot \mathrm{ml}^{-1}\right)$. The rest of the isolates $(42 \%)$ were sensitive to prochloraz.
\end{abstract}

Keywords: Oculimacula yallundae, Oculimacula acuformis, wheat, fungicide resistance, prochloraz

Abbreviations: No.: number; OY: Oculimacula yallundae; OA: Oculimacula acuformis

\section{Introduction}

Cereal stem base diseases are very important all over the world. Stem base disease complex in wheat includes more fungal pathogens belonging to different species and genera of Ascomycetes and Basidiomycetes (Fusarium, Gaeumannomyces, Microdochium, Oculimacula, Rhizoctonia etc.). The major foot disease of winter wheat in several European countries is eyespot caused by two different species: Oculimacula yallundae (Wallwork \& Spooner) Crous \& W. Gams and Oculimacula acuformis (Boerema, R. Pieters \& Hamers) Crous \& W. Gams (Leroux et al. 2013).

O. yallundae (OY) and O. acuformis (OA) differ in morphology, pathogenicity, occurrence, and sensitivity to fungicides (Wei et al. 2011). Both species coexist in the same fields and seem to follow similar life cycles (Lucas et al. 2000). Fungicide treatments to

\footnotetext{
*Corresponding author; E-mail: palicova@vurv.cz
} 
control wheat eyespot are most effective when applied between the end of tillering $(\mathrm{BBCH} 29)$ and the second node stage $(\mathrm{BBCH} 32)$. Active ingredients that are at least locally systemic are required for the chemical control of eyespot (Leroux et al. 2013). The chemical control of wheat eyespot became widespread in the 1970s with the introduction of benzimidazole fungicides. In the early $1980 \mathrm{~s}$, the selection of resistant strains led to the replacement of these fungicides with sterol $14 \alpha$-demethylation inhibitors (DMIs). These compounds include triazoles, imidazole prochloraz, prothioconazole etc. The anilinopyrimidine cyprodinil was registered in France in the 1990s, when the resistance to triazoles and prochloraz was encountered in practice (Leroux and Gredt 1997). Later two new active ingredients were introduced - boscalid and metrafenone (Avenot et al. 2010; Opalski et al. 2006). In the Czech Republic medium level of Oculimacula spp. resistance to prochloraz was found during monitoring 2012-2015 (Matušinsky et al. 2017).

In addition to chemical protection, resistant varieties can be grown. So far, 3 genes of resistance to eyespot have been described - Pch1, Pch2, Pch3. Gene Pch1 is the most effective one and it is possessed by cultivars Annie, Beduin, Bonanza, Hermann, Iridium, Manager, Princeps, Pankratz, Partner, Rebell etc. (Dumalasová et al. 2015). Pch1 does not protect plants absolutely but symptoms are less intense and stalks are not broken (Palicová et al. 2018).

The aim of this study was to observe the reaction of selected OY and OA isolates originated from winter wheat to ten fungicides registered to protect wheat against eyespot. We wanted to compare the susceptibility of tested isolates to fungicides based on different active ingredients. Moreover the susceptibility of pathogens to prochloraz was observed. There is still not enough information about resistance to fungicides in the Czech Republic.

\section{Materials and Methods}

\section{Sampling of stem bases and fungal isolates}

A total of 59 samples of winter wheat stems infected by eyespot were collected in different parts of the Czech Republic from April to June in 2015-2017. The samples were collected from the fields with high incidence of eyespot in spite of the fact that the application of fungicides were done properly. Stem bases were cut from the infected wheat plants, surfacesterilized for 2 minutes in 5\% sodium hypochlorite solution and rinsed in sterile distilled water. Subsequently the stem segments were placed on commercial potato dextrose agar (PDA-Himedia) containing antibiotics to inhibit bacterial growth (ampicillin $50 \mu \mathrm{g} \cdot \mathrm{ml}^{-1}$ or chloramphenicol $100 \mu \mathrm{g} \cdot \mathrm{ml}^{-1}$ ). In case of plants collected in June the grey mycelium of pathogen was taken from the inner part of the stem and put directly on PDA with antibiotics. Petri dishes were incubated at $18{ }^{\circ} \mathrm{C}$ under the UV-C light for 5 days. Developing colonies were transferred to new PDA plates for species identification by PCR.

\section{Determination of Oculimacula spp. by PCR}

Oculimacula spp. isolates were subjected to molecular diagnostics for identification of $\mathrm{OY}$ and OA because microscopic differences between both species are not always well 
discernible. Mycelia were ground to a fine powder in a mortar using liquid nitrogen, homogenized and total genomic DNA was extracted using Qiagen DNeasy ${ }^{\circledR}$ Plant Mini Kit. Species-specific primers were used as described previously for OY and OA (Walsh et al. 2005). Each reaction contained extracted stem base DNA, a negative control and a positive control of purified DNA from mycelium of each fungal species. Aliquots $(10 \mu \mathrm{l})$ of amplification products were electrophoresed through $1.7 \%$ agarose gels prepared using TAE buffer and stained with ethidium bromide.

\section{Resistance to fungicides}

The method of small discs saturated with fungicides was used for resistance tests. The set of 104 Oculimacula spp. isolates was tested for sensitivity to 10 fungicides based on various active ingredients (Table 1). The trial was separated into 3 parts according to year of sampling. Some fungicides were used only in one year because of their low efficacy or their unavailability. All fungicides were registered to eyespot (website of Central Institute for Supervising and Testing in Agriculture of CR). Mycelial discs $0.5 \mathrm{~mm}$ in diameter were cut from colony margins and transferred into the centre of the Petri dish. A filter paper disc saturated with a fungicide was placed $20 \mathrm{~mm}$ from the pathogen; a control disc immersed in sterile distilled water was placed opposite $20 \mathrm{~mm}$ from the pathogen (Fig. 1). The Petri dishes were incubated for 4 weeks at $18{ }^{\circ} \mathrm{C}$ in the dark. Two perpendicular diameters of the colony were measured and compared with the control dishes without fungicide; the percentage growth relative to the control was counted. Each of the tested isolates was cultivated in three replications. The data were analysed by the UNISTAT 6.5 package (UNISTAT Ltd., London, UK) and Statistica 12 (Statsoft, Tulsa, USA) - Analysis of Variance, Multiple Comparison by Tukey.

Table 1. The combination of active ingredients into the tested fungicides

\begin{tabular}{|c|c|}
\hline No. of fungicide & Active ingredients \\
\hline 1 & tetraconazole $\left(70 \mathrm{~g} \cdot 1^{-1}\right)$, thiophanate-methyl $\left(233 \mathrm{~g} \cdot 1^{-1}\right)$ \\
\hline 2 & cyprodinil $\left(250 \mathrm{~g} \cdot \mathrm{l}^{-1}\right)$, propiconazole $\left(62.5 \mathrm{~g} \cdot \mathrm{l}^{-1}\right)$ \\
\hline 3 & prochloraz $\left(450 \mathrm{~g} \cdot 1^{-1}\right)$ \\
\hline 4 & epoxiconazole $\left(41.6 \mathrm{~g} \cdot \mathrm{1}^{-1}\right)$, fluxapyroxad $\left(41.6 \mathrm{~g} \cdot \mathrm{l}^{-1}\right)$, pyraclostrobin $\left(66.6 \mathrm{~g} \cdot \mathrm{l}^{-1}\right)$ \\
\hline 5 & epoxiconazole $\left(62.5 \mathrm{~g} \cdot \mathrm{1}^{-1}\right)$, fenpropimorph $\left(200 \mathrm{~g} \cdot \mathrm{l}^{-1}\right)$, metrafenone $\left(75 \mathrm{~g} \cdot \mathrm{1}^{-1}\right)$ \\
\hline 6 & prothioconazole $\left(175 \mathrm{~g} \cdot \mathrm{1}^{-1}\right)$, trifloxystrobin $\left(15 \mathrm{~g} \cdot \mathrm{1}^{-1}\right)$ \\
\hline 7 & bixafen $\left(50 \mathrm{~g} \cdot \mathrm{1}^{-1}\right)$, prothioconazole $\left(100 \mathrm{~g} \cdot \mathrm{1}^{-1}\right)$, spiroxamine $\left(250 \mathrm{~g} \cdot \mathrm{1}^{-1}\right)$ \\
\hline 8 & prochloraz $\left(400 \mathrm{~g} \cdot \mathrm{1}^{-1}\right)$, propiconazole $\left(90 \mathrm{~g} \cdot \mathrm{1}^{-1}\right)$ \\
\hline 12 & prothioconazole $\left(125 \mathrm{~g} \cdot \mathrm{l}^{-1}\right)$, tebuconazole $\left(125 \mathrm{~g} \cdot \mathrm{1}^{-1}\right)$ \\
\hline 13 & boscalid $\left(133 \mathrm{~g} \cdot \mathrm{l}^{-1}\right)$, metconazole $\left(60 \mathrm{~g} \cdot \mathrm{l}^{-1}\right)$ \\
\hline
\end{tabular}




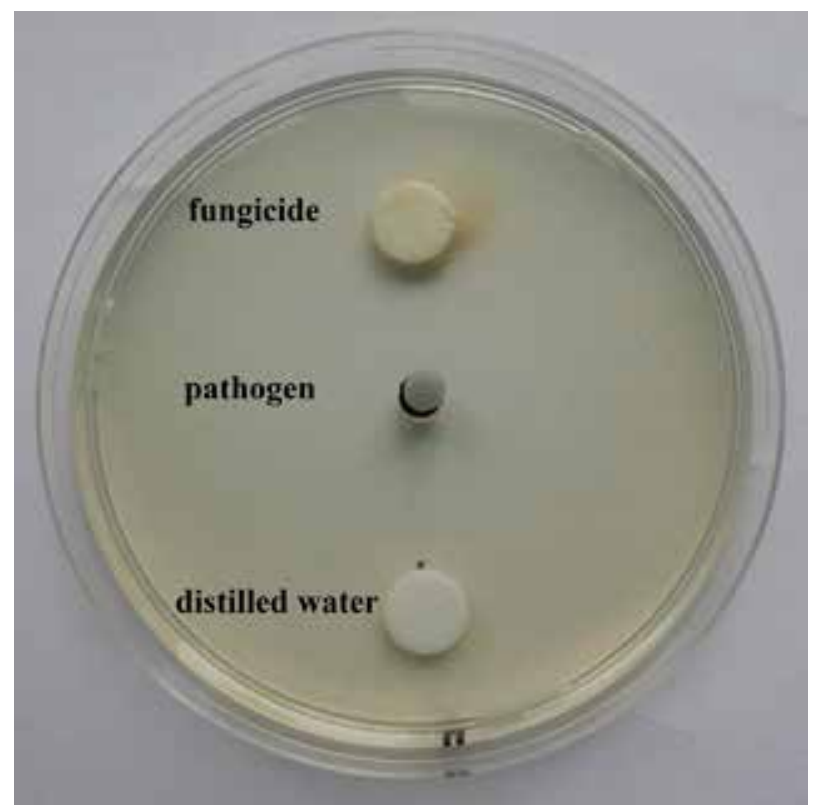

Figure 1. The method of small discs saturated with fungicides used for resistance tests (after 4 weeks at $18{ }^{\circ} \mathrm{C}$ in the dark)

\section{Resistance to prochloraz}

The inhibitory effect of prochloraz on the mycelial radial growth of Oculimacula spp. was tested using the agar dilution method. During 2015-2017, a total of 114 isolates were tested (2015 - 30 isolates, $2016-1$ isolate, $2017-83$ isolates). To supply inoculum, isolates of the analysed fungi were cultured on a PDA medium at $18{ }^{\circ} \mathrm{C}$ for 10 days in darkness. Mycelial discs $1.5 \mathrm{~mm}$ in diameter were cut from colony margins and transferred onto PDA plates containing the fungicide prochloraz (SigmaAldrich). The samples were established in five fungicide concentrations, namely $0.0,0.01,0.1,1.0$, and 10.0 $\mu \mathrm{g} \cdot \mathrm{ml}^{-1}$. Each of the tested isolates was cultured in four replications. After incubation at $18^{\circ} \mathrm{C}$ for 14 days colony diameters were measured and effective doses $\left(\mathrm{ED}_{50}\right)$ were calculated by probit analysis (Finney 1971).

\section{Results}

Determination of Oculimacula spp. by PCR

In total 143 Oculimacula spp. isolates were obtained from 59 winter wheat samples infected by eyespot in the years 2015-2017. Wheat samples were collected in the most important growing areas in the Czech Republic (17 districts, 24 localities) - see Fig. 2. Oculimacula species were determined by PCR. OY isolates prevailed (122) over OA 


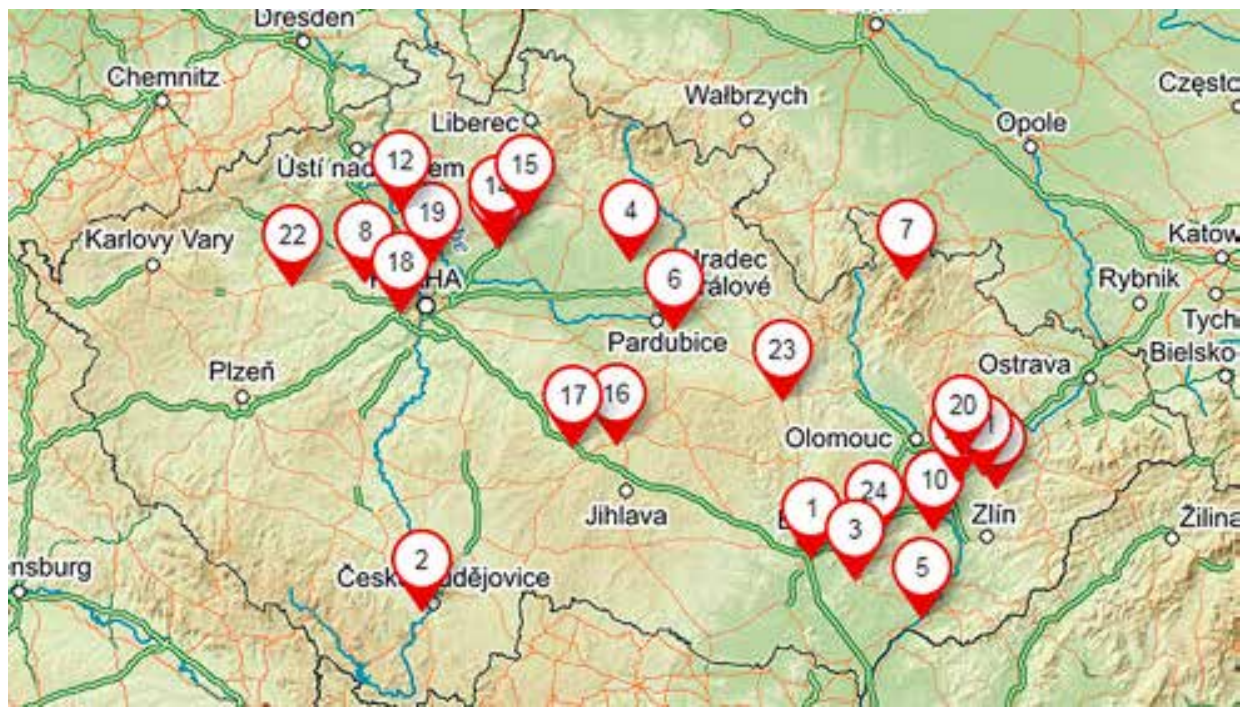

Figure 2. Localities of eyespot incidence in the Czech Republic

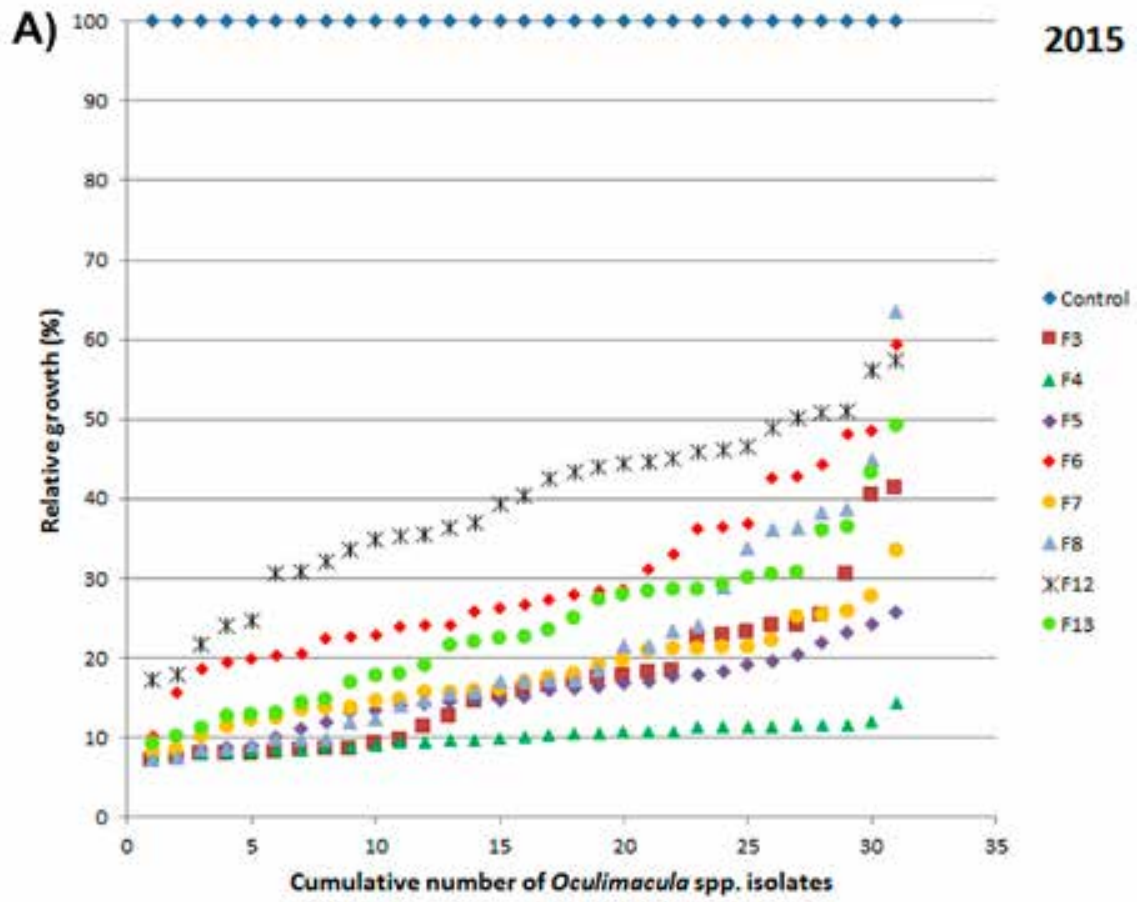

Figure 3. A) Reaction of Oculimacula spp. strains to different fungicides in the year 2015 

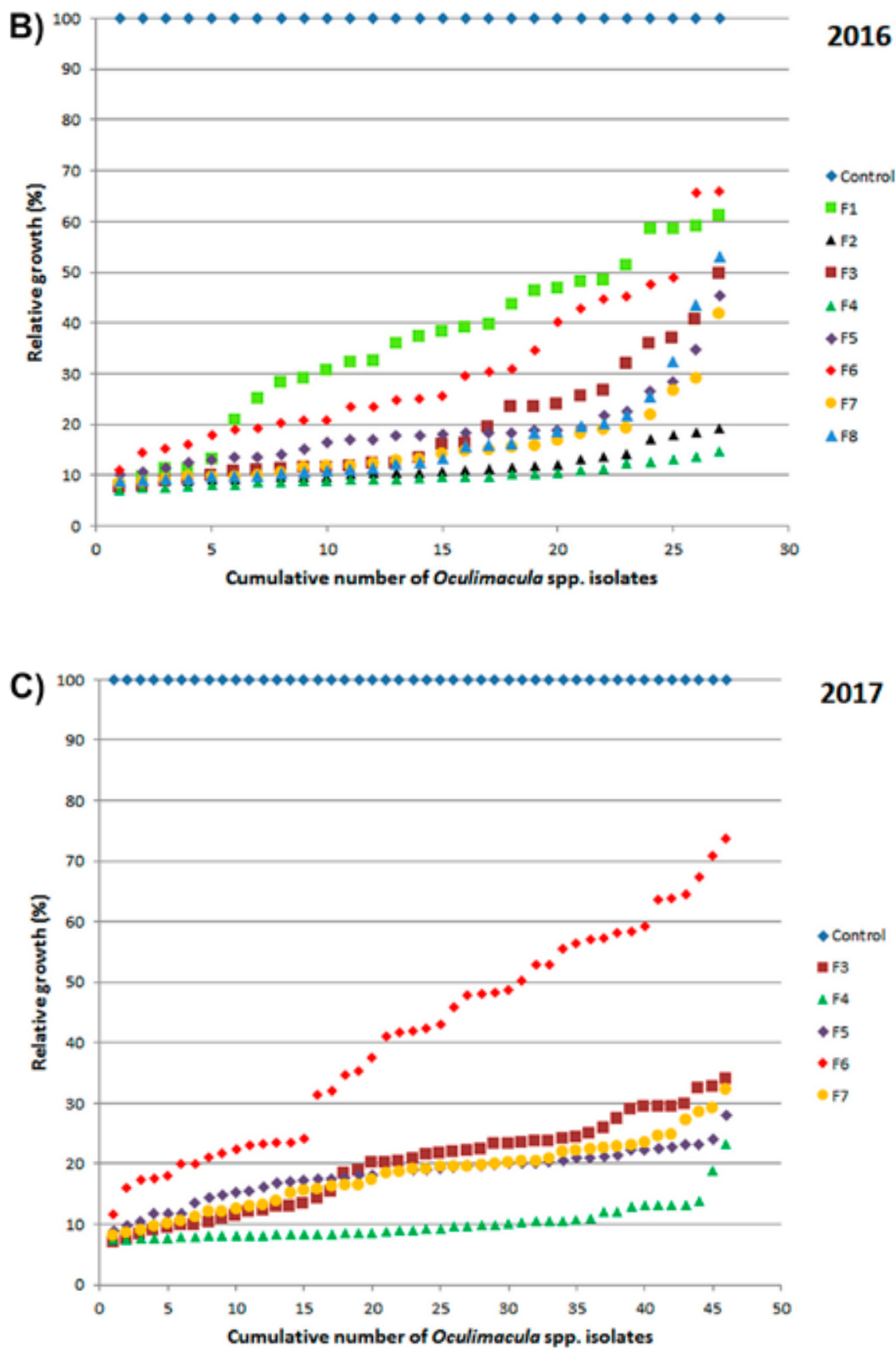

Figure 3. B), C) Reaction of Oculimacula spp. strains to different fungicides in the years 2016-2017 
isolates (12) and 9 mixed isolates of both species. OA was detected only in five localities. OA predominated only on one locality strongly affected by eyespot (locality number 16 - Fig. 2). We found both Oculimacula species together in one stem only five times.

\section{Resistance to fungicides}

The set of Oculimacula spp. strains tested for resistance to fungicides showed statistically significant differences among strains, among fungicides and the significant interaction strain $\times$ fungicide was proved. The highest growth reduction of the pathogen was proved using fungicide no. 4 with 3 active ingredients: epoxiconazole, fluxapyroxad, pyraclostrobin in all three years (Fig. 3). The mean percentage growth compared with the control was only $10 \%$ (Table 2 ). High efficacy was also observed using fungicide no. 2 with cyprodinil and propiconazole but termination of marketing of this fungicide stopped our next experiments. The lowest efficacy was detected using fungicide no. 6 with prothioconazole and trifloxystrobin. The mean percentage growth of this fungicide compared with the control was $29.6 \%$ in $2015,30.5 \%$ in 2016 and $41 \%$ in 2017 . Fungicides no. 12 and 1 (prothioconazole + tebuconazole and tetraconazole + thiophanate-methyl) showed low efficacy, too.

Table 2. Mean percentage growth of Oculimacula spp. isolates using different fungicides compared with control without fungicides

\begin{tabular}{|c|c|c|c|c|c|c|c|c|}
\hline \multicolumn{3}{|c|}{2015} & \multicolumn{3}{|c|}{2016} & \multicolumn{3}{|c|}{2017} \\
\hline Fungicide & Growth & H. g. & Fungicide & Growth & H. g. & Fungicide & Growth & H. g. \\
\hline 4 & 10,0703 & $\mathrm{a}$ & 4 & 9,8897 & $\mathrm{a}$ & 4 & 10,1409 & $\mathrm{a}$ \\
\hline 5 & 15,4598 & b & 2 & 11,6711 & b & 7 & 18,2253 & b \\
\hline 3 & 16,7304 & $\mathrm{bc}$ & 7 & 15,4487 & $\mathrm{c}$ & 5 & 18,2873 & $\mathrm{~b}$ \\
\hline 7 & 17,8457 & $\mathrm{c}$ & 8 & 16,9894 & d & 3 & 19,6081 & $\mathrm{c}$ \\
\hline 8 & 21,0433 & d & 5 & 18,8683 & $\mathrm{e}$ & 6 & 40,9971 & $\mathrm{~d}$ \\
\hline 13 & 23,6787 & $\mathrm{e}$ & 3 & 19,1330 & $\mathrm{e}$ & 0 & 100,0000 & $\mathrm{e}$ \\
\hline 6 & 29,5517 & f & 6 & 30,4905 & f & & & \\
\hline 12 & 38,9795 & $\mathrm{~g}$ & 1 & 35,7087 & g & & & \\
\hline 0 & 100,0000 & $\mathrm{~h}$ & 0 & 100,0000 & $\mathrm{~h}$ & & & \\
\hline
\end{tabular}

H. g. (homogeneous groups) - ANOVA, multiple comparisons by Tukey's method were used $(P=95 \%)$, the means in columns followed by the same letter are not significantly different from each other; fungicide no. $0=$ control without fungicide.

Differences between the reaction of OY and OA isolates were observed. Good efficacy of prochloraz + propiconazole was found in OY isolates but not in OA isolates. The most effective fungicide (epoxiconazole + fluxapyroxad + pyraclostrobin) and least effective one (prothioconazole + tebuconazole) were identical in both species. All fungicides were more effective for OY than for OA except for fungicide no. 6 (prothioconazole + trifloxystrobin). 


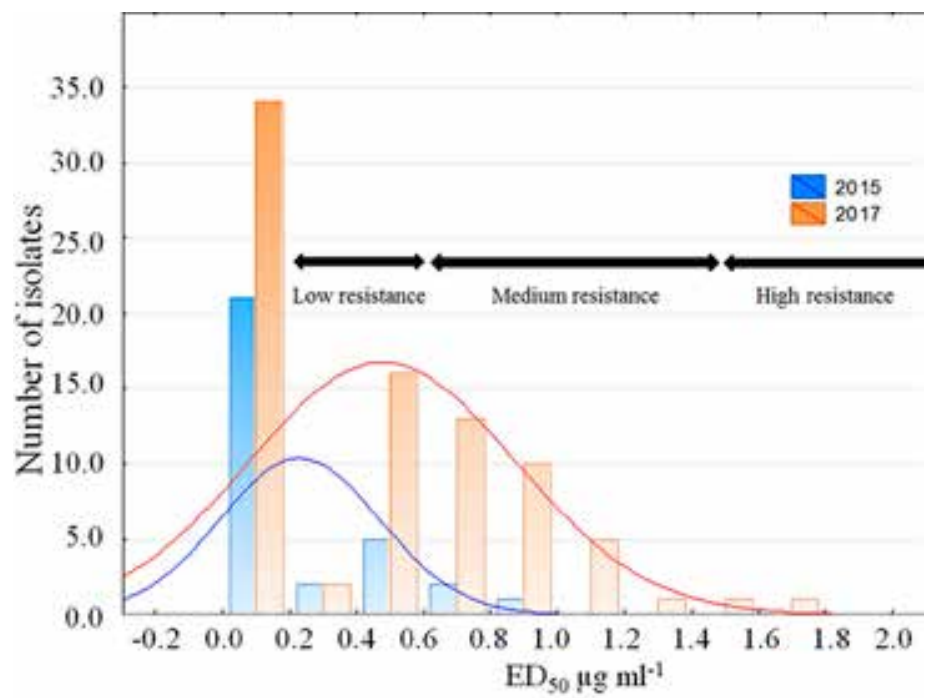

Figure 4. Distribution of prochloraz $\mathrm{ED}_{50} \mathrm{~s}$ for isolates of Oculimacula spp. collected in $2015(\mathrm{n}=30)$ and in $2017(\mathrm{n}=83)$

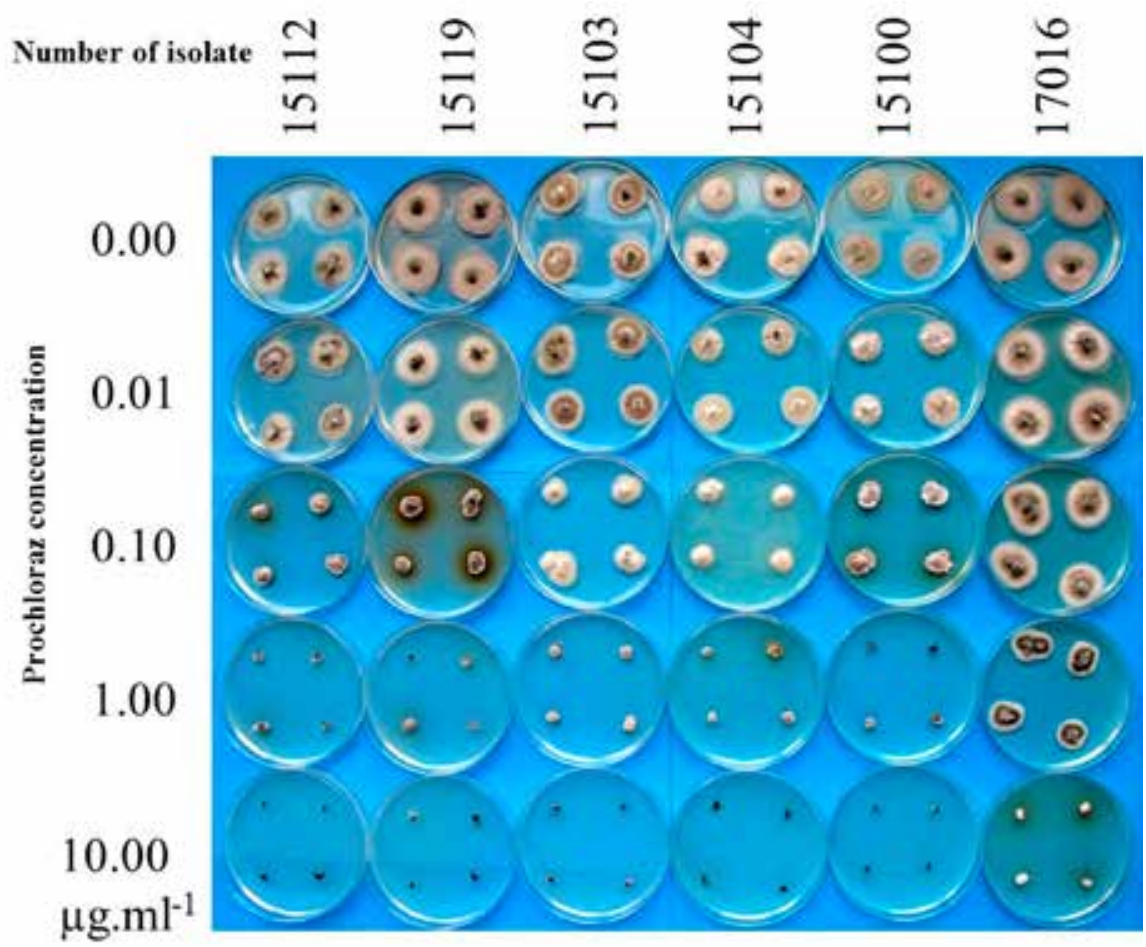

Figure 5. Inhibitory effect of prochloraz on mycelial radial growth of Oculimacula spp. Isolate no. 15112 $\left(\mathrm{OY}+\mathrm{OA}, \mathrm{ED}_{50}=0.1\right.$ sensitive $)$, no. $15119\left(\mathrm{OY}, \mathrm{ED}_{50}=0.1\right.$ sensitive $)$, no. $15103\left(\mathrm{OA}, \mathrm{ED}_{50}=0.2\right.$ low resistant), no. $15104\left(\mathrm{OA}, \mathrm{ED}_{50}=0.1\right.$ sensitive $)$, no. $15100\left(\mathrm{OA}, \mathrm{ED}_{50}=0.1\right.$ sensitive $)$, no. $17016\left(\mathrm{OY}, \mathrm{ED}_{50}=0.8\right.$ moderately resistant) 


\section{Resistance to prochloraz}

The inhibitory effect of prochloraz on the mycelial radial growth of Oculimacula spp. was tested using the agar dilution method. Of the total number of 114 evaluated Oculimacula spp. isolates, 48 showed sensitivity, 34 showed low resistance, 31 showed medium resistance and only 1 isolate was high resistant according to the classification of Dyer et al. (2000). OY isolates prevailed among the sensitive isolates; OA and mixed isolates $\mathrm{OY}+\mathrm{OA}$ were less frequent. Differences between the years 2015 and 2017 are shown in the Fig. 4. The resistance level to prochloraz was higher for isolates from 2017. Fig. 5 shows differences between growths of some isolates.

\section{Discussion}

In conclusion, OY was prevalent causal agent of eyespot on the examined localities (except one) in the Czech Republic. Sometimes both Oculimacula species occurred together in one stem. In the study from Lithuania cereal stem bases were mostly colonised by both species (Ramanauskiene and Gaurilčikiene 2016). Bierman et al. (2002) described a stable coexistence of about $50 \%$ of both species in unsprayed and carbendazim sprayed plots for five seasons in the UK. The prevalence of OA in population can reduce the efficacy of fungicides which is sufficient in localities with prevalence of OY. Knowledge of the distribution of $\mathrm{OA}$ and $\mathrm{OY}$ strains resistant to fungicides allows resistance management strategies for eyespot fungi in winter wheat to be proposed. Such studies and strategies for eyespot have been done e.g. in France (Leroux et al. 2013) but not in the Czech Republic. This study and previous ones (Matušinsky et al. 2017; Palicová et al. 2018) have started work on this topic.

The method of small discs saturated with fungicides was used for resistance tests. The set of 104 Oculimacula spp. isolates was tested for sensitivity to 10 fungicides available on the market against eyespot in the Czech Republic. In these trials the fungicides which are used by farmers in field conditions were tested in vitro. The decrease of efficacy of fungicide no. 6 (prothioconazole+trifloxystrobin) has been observed since 2015. In 2017 the mean growth of Oculimacula spp. isolates after fungicide application compared with control was $40 \%$.

The inhibitory effect of prochloraz on the mycelial radial growth of Oculimacula spp. was proved and was compared with effect of fungicide no. 8 (prochloraz + propiconazole). The correlation between results of these two tests was not proved. In period 20122015 only some Oculimacula spp. isolates showed low (14\%) to medium (6\%) resistance to prochloraz (Matušinsky et al. 2017). In our study (2015-2017) 30\% of isolates showed low resistance, $27 \%$ medium resistance and 1\% high resistance. Medium and high resistant isolates to prochloraz were mostly collected in 2017 and belonged to OY. Only 3 moderately resistant isolates came from the same stem from 2015. There is an obvious trend to fungicide resistance. In France, for example, resistance to prochloraz evolved successively in Oculimacula spp. and is now well established (Leroux et al. 2013). 
We did not confirm a higher probability of resistance to fungicides in OA than in OY probably because of much lower number of tested OA isolates. OA is considered to be naturally resistant to the class of DMI fungicides (Leroux et al. 2013).

\section{Acknowledgements}

This study was supported by Ministry of Agriculture of the Czech Republic, projects No. MZe-RO0418, MZE-RO1118 and No. QJ1530373. We would like to thank Alena Hanzalová for help with sample collection and Milena Bernardová for providing of fungicides for the tests.

\section{References}

Avenot, H.F., Michailide, T.J. 2010. Progress in understanding molecular mechanisms and evolution of resistance to succinate dehydrogenase inhibiting (SDHI) fungicides in phytopathogenic fungi. Crop Prot. 29(7):643-651.

Bierman, S.M., Fitt, B.D.L., van den Bosch, F., Bateman, G.L., Jenkyn, J.F., Welham, S.J. 2002. Changes in populations of the eyespot fungi Tapesia yallundae and T. acuformis under different fungicide regimes in successive crops of winter wheat, 1984-2000. Plant Pathol. 51:191-201.

Dumalasová, V., Palicová, J., Hanzalová, A., Bížová, I., Leišová-Svobodová, L. 2015. Eyespot resistance gene Pch1 and methods of study of its effectiveness in wheat cultivars. Czech J. Genet. Plant 51:166-173.

Dyer, P.W., Hansen, J., Delaney, A., Lucas, J.A. 2000. Genetic control of resistance to the sterol 14 $\alpha$-demethylase inhibitor fungicide prochloraz in the cereal eyespot pathogen Tapesia yallundae. Appl. Environ. Microb. 66(11):4599-4604.

Finney, D.J. 1971. Probit analysis (Third ed.). Cambridge, UK: Cambridge University Press.

Leroux, P., Gredt, M. 1997. Evolution of fungicide resistance in the cereal eyespot fungi Tapesia yallundae and Tapesia acuformis in France. Pestic. Sci. 51:321-327.

Leroux, P., Gredt, M., Remuson, F., Micoud, A., Walker, A.-S. 2013. Fungicide resistance status in French populations of the wheat eyespot fungi Oculimacula acuformis and Oculimacula yallundae. Pest Manag. Sci. 69:15-26.

Lucas, J.A., Dyer, P.S., Muray, T.D. 2000. Pathogenicity, host specificity, and population biology of Tapesia spp., causal agents of eyespot disease in cereals. Adv. Bot. Res. 33:226-258.

Matušinsky, P., Svačinová, I., Jonavičienè, A., Tvarůžek, L. 2017. Long-term dynamics of causative agents of stem base diseases in winter wheat and reaction of Czech Oculimacula spp. and Microdochium spp. populations to prochloraz. Eur. J. Plant Pathol. 148:199-206.

Opalski, K.S., Tresch, S., Kogel, K.H., Grossmann, K., Kohle, H., Huckelhoven, R. 2006. Metrafenone: studies on the mode of action of a novel cereal powdery mildew fungicide. Pest Manag. Sci. 62(5):393-401.

Palicová, J., Matušinsky, P., Dumalasová, V., Hanzalová, A., Bížová, I. 2018. Resistance of winter wheat cultivars to eyespot and characterisation of causal agents of the disease. Plant Protect. Sci. 54(1):24-30.

Ramanauskienè, J., Gaurilčikienè, J. 2016. Incidence of eyespot in winter wheat and quantification of the fungi Oculimacula acuformis and O. yallundae in Lithuania. J. Plant Dis. Protect. 123(2):75-81.

Walsh, K., Korimbocus, J., Boonham, N., Jennings, P., Hims, M. 2005. Using real-time PCR to discriminate and quantify the closely related wheat pathogens Oculimacula yallundae and Oculimacula acuformis. J. Phytopathol. 153:715-721.

Wei, L., Muranty, H., Zhang, H. 2011. Advances and prospects in wheat eyespot research: contributions from genetics and molecular tools. J. Phytopathol. 159:457-470. 